\title{
ANALISIS BIAYA SAKIT \\ PERSPEKTIF MASYARAKAT PADA PENDERITA DRESS \\ (Drug Reaction with Eosinophilia and Systemic Symptoms) \\ DI RSUP Dr. SARDJITO YOGYAKARTA \\ COST OF ILLNESS ANALYSIS ON PERSPECTIVE COMMUNITY IN DRESS (Drug Reaction with Eosinophilia and Systemic Symptoms) IN RSUP Dr. SARDJITO YOGYAKARTA
}

\author{
Musa Fitri Fatkhiya* ${ }^{* 1}$, Dyah Aryani Perwitasari ${ }^{1}$, Sri Awalia Febriana ${ }^{2}$ \\ ${ }^{1}$ Fakultas Farmasi, Universitas Ahmad Dahlan, Yogyakarta \\ ${ }^{2}$ Departemen Dermatologi dan Venereologi RSUP Dr. Sardjito Yogyakarta \\ ${ }^{2}$ Fakultas Kedokteran dan Keperawatan, Universitas Gadjah Mada, Yogyakarta \\ *Penulis koresponding, e-mail: musafitri29@gmail.com
}

\begin{abstract}
ABSTRAK
Penyakit akibat induksi obat merupakan suatu efek yang tidak diinginkan yang dapat menyebabkan mortalitas maupun morbiditas. Reaksi pada kulit yang mungkin muncul dapat berupa efek ringan hingga berat seperti Severe Cutaneous Adverse Reaction (SCAR) sehingga memerlukan perhatian khusus. SCAR bukan hanya masalah kesehatan tetapi juga menjadi beban keuangan yang signifikan untuk individu yang terkena dampak. Salah satu variasi SCAR yang memiliki periode latensi yang panjang adalah DRESS (Drug Reaction With Eosinophilia and Systemic Symptom). Penelitian ini bertujuan untuk mengetahui rata-rata biaya medis langsung, biaya non medis langsung dan biaya tidak langsung pada pasien DRESS. Pengambilan data dalam penelitian ini secara cohort retrospective di RSUP Dr. Sardjito Yogyakarta tahun 20152018 pada pasien DRESS akibat induksi NSAID, antibiotik, antikonvulsan, antiretroviral, antituberkulosis berdasarkan data rekam medis, data akuntansi serta CRF. Hasil data dianalisis secara deskriptif dengan Microsoft office excel. Rata-rata biaya medis langsung rawat inap sebesar Rp. 11.643.405 dengan komponen biaya tertinggi adalah biaya obat $(31 \%)$, biaya tindakan medis $(27 \%)$, biaya laboratorium $(24 \%)$, biaya akomodasi (15\%) dan biaya lainnya (3\%). Biaya rawat jalan sebesar Rp. 1.027.894 dengan komponen tertinggi yaitu biaya tindakan medis (39\%), biaya laboratorium $(36 \%)$, biaya obat $(14 \%)$, biaya lainnya $(6 \%)$ dan terendah adalah biaya transportasi (5\%). Rata-rata biaya non medis langsung sebesar Rp 491.035 dan biaya tidak langsung adalah sebesar Rp. 1.675 .369 yang merupakan biaya loss income.. Biaya medis langsung merupakan biaya tertinggi dibandingkan biaya non medis langsung dan biaya tidak langsung.
\end{abstract}

Kata kunci : Perspektif masyarakat, Drug Reaction with Eosinophilia and Systemic Symptom, biaya medis langsung, biaya non medis langsung, biaya tidak langsung 


\section{ABSTRACT}

Drug induced disease is an undesirable effect that can cause both mortality and morbidity. Reactions that may appear on the skin can be in the form of mild to severe effects such as Severe Cutaneous Adverse Reaction (SCAR), that require special attention. SCAR is not only a health problem but also a significant financial burden for affected individuals. One variation of SCAR that has a long latency period is DRESS (Drug Reaction With Eosinophilia and Systemic Symptom). This study aims to find the average direct medical costs, non-direct medical costs and indirect costs in DRESS patients. Retrieval of data in this cohort retrospective study at Dr. RSUP Hospital. Sardjito Yogyakarta in 2015-2018 in DRESS patients due to NSAID induction, antibiotics, anticonvulsants, antiretrovirals, antituberculosis based on medical record data, accounting data and CRF. The results of the data were analyzed descriptively with Microsoft office excel. The average direct medical costs of hospitalization were Rp. 11,643,405 with the highest cost components being drug costs (31\%), medical treatment costs (27\%), laboratory fees (24\%), accommodation costs (15\%) and other costs (3\%). Outpatient fee of Rp. 1,027,894 with the highest components, namely the cost of medical treatment (39\%), laboratory costs (36\%), drug costs (14\%), other costs (6\%) and the lowest are transportation costs (5\%). The average non-direct medical costs are IDR 491,035 and indirect costs are Rp. 1,675,369 which is the cost of loss income. Direct medical costs are the highest costs compared to non-direct medical costs and indirect costs.

Keywords: Community Perspective, Drug Reaction with Eosinophilia and Systemic Symptom, Direct medical costs, Direct non medical cost, Indirect costs

\section{PENDAHULUAN}

Penyakit akibat induksi obat (Drug Induced Disease/DID) merupakan suatu efek yang tidak diinginkan dari penggunaan suatu obat yang dapat menyebabkan mortalitas maupun morbiditas. Kejadian DID disertai gejala sehingga memerlukan perawatan medis. Kejadian DID ada yang sudah diantisipasi ataupun sebelumnya tidak ada antisipiasi (Tandon et al., 2015). Reaksi yang tidak diinginkan akibat induksi obat dapat berupa reaksi akut seperti syok anafilaksis, gangguan pernafasan ataupun gangguan kutaneus seperti urtikaria dan angiodema. Reaksi obat pada kulit yang mungkin muncul dapat berupa efek yang ringan hingga pada tingkat yang parah seperti Severe Cutaneous Adverse Reaction (SCAR) sehingga memerlukan perhatian khusus(Sánchez-Borges et al., 2010).

Pada manajemen SCARs membutuhkan banyak perawatan biaya medis langsung. SCAR bukan hanya masalah kesehatan tetapi juga menjadi beban keuangan yang signifikan untuk individu yang terkena dampak (Yang et al., 2019). Salah satu variasi 
SCAR yang memiliki periode latensi yang panjang adalah DRESS (Drug Reaction With Eosinophilia and Systemic Symptom). DRESS atau ruam kulit dengan eosinofilia dan gejala sistemik sindrom adalah penyakit yang berbeda, merupakan penyakit parah atau berat dan idiosinkratik (Chen et al., 2010). Nama DRESS menunjukkan 2 hal penting dalam karakteristik penyakitnya : keterlibatan multi-sistemik dan sering ditemukan adanya eosinofilia (Kano and Shiohara, 2013). Meskipun insidensi rendah, DRESS dikaitkan dengan mortalitas tinggi, biaya perawatan kesehatan yang sangat tinggi dan gejala sisa autoimun kronis (Wu et al., 2018).

Terdapat laporan terkait biaya langsung kulit pada pasien SCAR, termasuk reaksi obat dengan eosinofilia dan gejala sistemik atau DRESS di pasien rawat inap dan kunjungan rawat atau rawat jalan (Yang et al., 2019). Sebagian besar pasien SCAR akan mengunjungi departemen rawat jalan setelah pulang dari dokter utama pasien, seperti klinik penyakit dalam dan klinik kulit, atau kunjungan ke departemen lain, seperti optalmologi, klinik nyeri, urologi, neuropsikiatri. Hal ini akan meningkatkan beban biaya karena pasien harus banyak meninggalkan aktivitasnya. Sehingga disimpulkan bahwa biaya untuk mengobati satu kasus SCAR sebanding dengan mengobati penyakit lima besar paling mahal secara nasional (Yang et al., 2019). Pasien dengan DRESS telah banyak mengeluarkan biaya untuk terapi saat rawat inap maupun terapi saat rawat jalan. Penelitian ini bertujuan untuk mengetahui rata-rata biaya medis langsung, biaya non medis langsung dan biaya tidak langsung pada pasien DRESS

\section{METODE PENELITIAN}

Penelitian ini adalah penelitian deskriptif dengan pengambilan data secara retrospektif. Analisa dilakukan untuk mengetahui rata-rata biaya medis langsung, biaya non medis langsung dan biaya tidak langsung pada pasien DRESS yang menjalani rawat inap dan rawat jalan. Populasi target dalam penelitian ini adalah seluruh pasien yang terdiagnosa DRESS dan menjalani rawat inap di Rumah Sakit Dr. Sardjito Yogyakarta sejak tahun 2015-2018 yang memenuhi kriteria inklusi. Hasil data dianalisis menggunakan analisis deskriptif. 


\section{Alat dan Bahan}

Data diperoleh dengan mengambil data pada catatan medik pasien di bagian Instalasi Catatan Medik (ICM), data biaya akuntansi pasien di bagian Instalasi Informasi dan Tehknologi (INSTI) RSUP Dr.Sardjito Yogyakarta serta dengan melakukan dokumentasi atau pencatatan menggunakan alat case report form (CRF).

\section{Jalannya Penelitian}

Data dianalisis secara deskriptif untuk melihat rata-rata biaya medis langsung, biaya non medis langsung dan biaya tidak langsung yang dikeluarkan oleh penderita DRESS di RSUP Dr. Sardjito Yogyakarta tahun 2015-2018 selama rawat inap dan rawat jalan yang dikeluarkan oleh pasien DRESS di RSUP Dr. Sardjito Yogyakarta. Biaya medis langsung (direct medical cost) yang akan dideskripsikan meliputi biaya akomodasi, biaya tindakan medis, biaya laboratorium, biaya obat dan biaya lainnya. Biaya non medis langsung (direct non medical cost) meliputi biaya transportasi dan biaya makanan, sedangkan untuk biaya tidak langsung (indirect cost) adalah biaya hilangnya produktivitas. Rata-rata biaya dihitung menggunakan Microsoft office excel. Seluruh biaya menggunakan nilai mata uang Rupiah. Pengambilan data dalam penelitian ini dilakukan tahun 2018 dengan mengambil data pada tahun 2015-2018, maka nilai mata uang tahun 2015, 2016, 2017 disesuaikan dengan tahun 2018. Penyesuaian biaya terhadap waktu dalam penelitian ini menggunakan Consumer Price Index (CPI). CPI dilakukan untuk merekam perubahan harga beli di tingkat konsumen (purchasing cost) dari sekelompok tetap barang dan jasa (fixed basket) yang pada umumnya dikonsumsi masyarakat (Badan pusat statistik, 2016).

\section{HASIL DAN PEMBAHASAN}

\section{A. Biaya Medis Langsung (Direct Medical Cost)}

Tabel I. Biaya medis langsung pada pasien DRESS di RSUP Dr. Sardjito Yogyakarta tahun 2015-2018

\begin{tabular}{|c|c|c|c|c|c|c|c|}
\hline \multirow[b]{2}{*}{ Biaya } & \multicolumn{5}{|c|}{ Komponen Biaya } & \multirow[b]{2}{*}{ Total } & \multirow{2}{*}{$\begin{array}{l}\text { Rata-Rata } \\
\text { tiap pasien }\end{array}$} \\
\hline & $\begin{array}{c}\text { Laboratoriu } \\
\mathbf{m}\end{array}$ & Akomodasi & Tindakan & Obat & Lainnya & & \\
\hline $\begin{array}{l}\text { Rawat } \\
\text { Inap }\end{array}$ & $\begin{array}{c}54.141 .189 \\
(24 \%)\end{array}$ & $\begin{array}{c}32.613 .466 \\
(15 \%)\end{array}$ & $\begin{array}{c}59.517 .981 \\
(27 \%)\end{array}$ & $\begin{array}{c}68.767 .000 \\
(31 \%)\end{array}$ & $\begin{array}{c}6.185 .062 \\
(3 \%)\end{array}$ & 221.224 .698 & 11.643 .405 \\
\hline $\begin{array}{l}\text { Rawat } \\
\text { Jalan }\end{array}$ & $\begin{array}{c}7.012 .862 \\
(36 \%)\end{array}$ & $\begin{array}{c}953.762 \\
(5 \%)\end{array}$ & $\begin{array}{c}7.640 .525 \\
(39 \%)\end{array}$ & $\begin{array}{c}2.748 .736 \\
(14 \%)\end{array}$ & $\begin{array}{c}1.174 .098 \\
(6 \%)\end{array}$ & 19.529 .983 & 1.027 .894 \\
\hline
\end{tabular}


Biaya Medis Langsung adalah biaya yang harus dibayarkan untuk pelayanan kesehatan. Biaya ini meliputi biaya pengobatan, tenaga medis, biaya tes laboraturium, dan biaya pemantauan efektivitas dan efek samping (Budiharto and Kosen, 2008) . Pada Tabel I mencantumkan komponen biaya medis langsung rawat inap dan biaya medis langsung rawat jalan yang dikeluarkan pasien DRESS di RSUP dr. Sardjito Yogyakarta tahun 2015-2018. Data tersebut berdasarkan informasi biaya dari 19 subjek penelitian dengan rata-rata lama rawatan 9 hari. Total biaya rawat inap yang dihabiskan adalah sebesar Rp. 221.224.698 dengan rata-rata biaya yang dikeluarkan oleh satu pasien DRESS adalah Rp. 11.643.405. Total biaya langsung rawat jalan yang dihabiskan oleh 19 subjek penelitian dengan rata-rata kunjungan ulang 4 kali adalah sebesar Rp 19.529.983. Rata-rata biaya rawat jalan untuk satu pasien DRESS adalah Rp. 1.027.894. Hasil penelitian menunjukkan komponen biaya paling tinggi pada biaya medis langsung rawat inap adalah biaya obat (31\%), sedangkan pada biaya medis langsung rawat jalan yaitu biaya tindakan medis (39\%).

Komponen biaya yang termasuk dalam biaya rawat inap adalah biaya laboratorium, biaya akomodasi, biaya obat, biaya tindakan (pemeriksaan dan keperawatan) dan biaya lainnya. Biaya laboratorium berupa biaya pemeriksaan patologi klinik, biaya pemeriksaan radiodiagnostik. Biaya akomodasi dalam penelitian ini yaitu biaya sewa kamar ruang rawat yang tergantung pada kelas perawatan dan lama rawat pasien, semakin tinggi kelas perawatan ataupun semakin lama menjalani rawat inap maka biaya yang dikeluarkan akan semakin tinggi. Biaya obat meliputi biaya obat, biaya donor, biaya alat ataupun biaya bahan medis habis pakai selama perawatan. Yang termasuk dalam biaya tindakan adalah biaya pemeriksaan rawat jalan, biaya homecare, biaya pelayanan rawat inap (biaya kunjungan dokter) biaya keperawatan, biaya pelayanan non operatif dan biaya pemeriksaan IGD. Biaya lainnya pada biaya rawat inap terdiri dari biaya gas medis dan biaya pendaftaran.

Biaya obat merupakan komponen biaya medis langsung rawat inap terbanyak yaitu sebesar Rp. 68.767 .000 (31\%). Faktor yang mempengaruhi tingginya biaya yang dikeluarkan seperti biaya obat dan bahan habis pakai yang digunakan, biaya pemeriksaan dan keperawatan, biaya pelayanan patologi klinik karena digunakan oleh pasien setiap hari. Bahan habis pakai yang digunakan pasien DRESS harus sering 
diganti selama perawatan. Contoh nya seperti kapas, hypafix, kasa banyak digunakan untuk membersihkan luka. Selain itu pasien DRESS merupakan pasien dengan penyakit kulit maka selain obat oral, pasien juga akan menerima obat topikal. Dalam setiap kunjungan dokter spesialis dikenakan biaya sebesar Rp 125.000 dan Rp 75.000 untuk jasa keperawatan. Dalam satu hari rawat inap, kunjungan dokter dan jasa keperawatan dilakukan beberapa kali. Selain obat dan tindakan medis, tingginya biaya laboratorium juga disebabkan oleh pelayanan patologi klinik yang harus sering dilakukan pada pasien DRESS terkait dengan keterlibatan organ dan perkembangan penyakitnya. Faktor inilah yang menyebabkan peningkatan pada biaya yang dikeluarkan, sehingga akan berbanding lurus antara lama rawatan dengan biaya yang dikeluarkan. Semakin lama rawat inap, biaya yang dikeluarkan akan semakin besar (Yang et al., 2019).

Biaya transportasi merupakan biaya transportasi yang digunakan pasien DRESS saat akan menjalani rawat inap. Biaya akomodasi meliputi biaya ruang rawat inap. Besarnya biaya ruang rawat yang digunakan tergantung pada kelas yang dipilih. Biaya rawat inap kelas I AC Rp 326.000 per malam, kelas I non AC Rp 287.000 per malam, sedangkan kelas II AC Rp 217.000 per malam, kelas II non AC Rp 191.000 per malam dan biaya kelas III AC Rp 196.000 per malam dan kelas III non AC Rp 172.000 per malam. Besar kecilnya biaya ruang rawat dibedakan berdasarkan fasilitas yang diterima pasien. Karena pada penelitian ini menggunakan perspektif masyarakat, maka baik pasien BPJS ataupun pasien umum akan digunakan sebagai subjek penelitian. Pada penelitian lain, biaya untuk kamar dan makan menyumbang mayoritas dari total biaya perawatan kesehatan yaitu sebesar $32 \%$, diikuti oleh biaya untuk obat-obatan sebesar $25 \%$, tes laboratorium $20 \%$, dan biaya untuk prosedur, dan layanan dokter sebesar 23 $\%$ (Yang et al., 2019). Biaya medis langsung pada rawat inap lainnya terdiri dari biaya pendaftaran atau administrasi dan biaya gas medis. Biaya pendaftaran pasien yaitu Rp 40.000 dan biaya gas medis pasien Rp 178.000 per hari.

Rawat jalan adalah upaya pasien yang mempunyai keluhan kesehatan untuk memeriksakan dengan mendatangi tempat pelayanan kesehatan tanpa menginap. Namun prosedur dalam rawat jalan seperti ini khususnya pasien yang telah atau baru saja rawat inap sudah sesuai dengan ketentuan dan juga aturan yang benar. Artinya, pasien rawat jalan perlu mematuhi anjuran dokter dan kembali melakukan kontrol sesuai dengan jadwal yang sudah ditentukan sebelumnya. Pasien DRESS dalam penelitian ini 
membutuhkan rawat jalan dalam masa penyembuhan nya, maka akan sangat tepat untuk selalu mematuhi aturan dokter kapan harus melakukan kunjungan ulang atau kontrol. Hal ini penting, agar proses penyembuhan pasien DRESS bisa berjalan dengan mudah dan cepat.

Biaya medis langsung yang merupakan biaya tertinggi pada rawat jalan adalah biaya tindakan medis sebesar Rp 7.640 .525 (36\%). Biaya laboratorium merupakan biaya paling tinggi nomor dua. Biaya tindakan medis termasuk biaya pemeriksaan dan biaya keperawatan luka. Biaya obat selama rawat jalan meliputi biaya obat, biaya alat kesehatan dan BMHP. Jika dibandingkan dengan biaya lainnya, biaya obat juga memiliki angka pengeluaran yang besar yaitu nomor tiga setelah biaya tindakan medis dan biaya laboratorium. Biaya lain-lain yang termasuk dalam biaya rawat jalan meliputi biaya pendaftaran rawat jalan sebesar Rp. 13.000. Biaya transportasi termasuk dalam biaya dengan pengeluaran paling rendah diantara biaya medis langsung rawat inap lainnya. Biaya akomodasi atau transportasi meliputi biaya yang dikeluarkan pasien DRESS dalam melakukan kunjungan ulang. Biaya transportasi dihitung berdasarkan jarak tempuh dan jenis kendaraan yang digunakan pasien DRESS dalam melakukan kunjungan ulang, hal ini termasuk biaya penginapan apabila pasien berangkat dari luar kota. Namun dalam penelitian ini, semua pasien DRESS yang termasuk subjek penelitian berdomisili di Yogyakarta.

Total biaya langsung rawat jalan yang dihabiskan oleh 19 subjek penelitian dengan rata-rata lama rawatan 9 hari dan rata-rata kunjungan ulang 4 kali adalah sebesar Rp 19.529.983. Rata-rata biaya rawat jalan untuk satu pasien DRESS adalah Rp. 1.027.894. Kunjungan ulang yang dilakukan pasien DRESS pada penelitian ini memiliki tujuan poli yang berbeda-beda. Beberapa pasien kunjungan ulang ke poli kulit dan kelamin, beberapa ke poli penyakit dalam dan beberapa pasien DRESS kunjungan ulang atau kontrol ke poli pulmonologi. Ada juga pasien DRESS yang kunjungan ulang hanya untuk melakukan tes laboratorium seperti cek DLO (Darah Lengkap Otomatis), cek kadar SGOT/SGPT, cek kadar ureum, kadar kretinin dan lainnya.

Hasil penelitian menunjukkan total biaya medis langsung dari rawat inap dan rawat jalan adalah Rp 240.754.681. Perhitungan rata-rata biaya yang dikeluarkan oleh tiap pasien DRESS untuk rawat inap dan rawat jalan sebesar Rp 12.671.299. Jika dilihat 
biaya paling tinggi dihabiskan untuk biaya rawat inap. Hal ini dikarenakan banyaknya rincian yang terdapat pada biaya rawat inap seperti biaya tindakan baik oleh dokter ataupun oleh perawat selama rawat inap. Semakin lama rawatan, otomatis akan semakin meningkatkan biaya rawat inapnya sehingga akan wajar jika tingginya biaya dengan rata-rata lama rawatan 9 hari. Hal ini sesuai dengan penelitian Yang et al (2019), sebagian besar biaya dihabiskan untuk perawatan rawat inap. DRESS menghabiskan 40 $\%$ dari total biaya setelah biaya untuk SJS/TEN.

Selisih yang cukup jauh antara biaya rawat inap dan rawat jalan ini dapat disebabkan oleh banyak faktor. Pada biaya rawat jalan, setiap pasien melakukan kunjungan ulang, pasien hanya akan memeriksakan keluhan dalam satu poli, sehingga tidak terdapat biaya kunjungan dokter setiap hari ataupun biaya pemeriksaan oleh perawat. Selain itu dalam melakukan kunjungan ulang, pasien hanya diberikan obat. Tidak seperti dalam rawat inap pasien mendapatkan beberapa obat, alat kesehatan dan bahan medis habis pakai lainnya yang mengakibatkan meningkatnya biaya.

\section{B. Biaya non Medis Langsung (Direct non Medical Cost)}

Tabel II. Biaya non medis langsung pada pasien DRESS di RSUP dr. Sardjito Yogyakarta tahun 2015-2018

\begin{tabular}{|c|c|c|c|c|}
\hline \multirow[b]{2}{*}{ Jumlah Pasien } & \multicolumn{2}{|c|}{ Biaya non Medis Langsung } & \multirow[b]{2}{*}{ Total } & \multirow{2}{*}{$\begin{array}{l}\text { Rata-rata } \\
\text { tiap pasien }\end{array}$} \\
\hline & Transportasi & Makanan & & \\
\hline 19 & 2.332 .518 & 6.997 .140 & 9.329 .658 & 491.035 \\
\hline
\end{tabular}

Biaya non medis langsung yang tertera pada Tabel II meliputi biaya transportasi dan biaya makanan bagi penunggu pasien yang sudah disesuaikan dengan waktu dan nilai uang. Biaya transportasi ini meliputi biaya yang dikeluarkan keluarga pasien untuk datang dan pergi dari rumah sakit saat pasien rawat inap. Biaya transportasi dihitung berdasarkan jenis kendaraan yang digunakan keluarga pasien dan jarak yang ditempuh keluarga pasien dari tempat tinggal ke rumah sakit. Total biaya transportasi yang dikeluarkan adalah Rp 2.332.518. Jumlah ini didapatkan dari jarak rumah pasien dan rumah sakit Dr. Sardjito serta besarnya bahan bakar yang dikeluarkan pada jarak tersebut (liter) yang tergantung pada jenis kendaraan yang digunakan. Jenis kendaraan yang digunakan keluarga pasien yaitu kendaraan pribadi berupa sepeda motor dan 
mobil, 6 pasien menggunakan sepeda motor dan 14 pasien menggunakan mobil. Karena rata-rata jarak rumah pasien dengan rumah sakit yaitu $12 \mathrm{Km}$ dan tempat tinggal pasien masih berada dalam wilayah DIY, maka biaya yang dikeluarkan untuk transportasi juga tidak terlalu besar.

Biaya makanan yang dikeluarkan meliputi biaya makanan tiap anggota yang menjaga dan menunggu pasien selama perawatan. Biaya makanan dihitung berdasarkan lama rawat inap pasien DRESS, biaya yang dihabiskan dalam satu hari atau 3 kali makan dan jumlah anggota keluarga yang menunggu. Penunggu dalam setiap pasien DRESS yang menjalani rawat inap dalam penelitian ini antara 1 atau 2 orang keluarga pasien. Ada 9 pasien ditemani oleh 1 orang penunggu dan 10 pasien DRESS lainnya ditemani oleh 2 orang penunggu. Dalam penelitian ini diasumsikan biaya yang dikeluarkan untuk satu kali makan adalah Rp. 7.000. Total biaya makanan pada 19 pasien DRESS dengan rata-rata lama rawatan 9 hari adalah Rp 6.997.140.

Biaya makanan pada pasien DRESS lebih besar dibandingkan dengan biaya transportasi. Hal ini dapat disebabkan oleh jarak antara rumah sakit dan tempat tinggal pasien DRESS yang tidak terlalu jauh atau masih dalam wilayah DIY dan tidak ada pasien DRESS yang menggunakan transportasi umum sehingga biaya transportasi lebih kecil daripada biaya makanan. Selain itu, biaya makanan menjadi lebih besar karena 10 dari 9 pasien DRESS saat rawat inap ditemani oleh 2 orang penunggu, sehingga biaya makanan menjadi lebih besar.

\section{Biaya Tidak Langsung (Indirect Cost)}

Tabel III. Biaya tidak langsung pada pasien DRESS di RSUP dr. Sardjito Yogyakarta tahun 2015-2018

\begin{tabular}{ccc}
\hline Jumlah & Biaya tidak langsung & Rata-rata tiap pasien \\
\cline { 2 - 3 } Pasien & loss income & \\
\hline $\mathbf{1 9}$ & 31.832 .018 & 1.675 .369 \\
\hline
\end{tabular}

Biaya tidak langsung (indirect cost) yang tersaji pada Tabel III adalah biaya yang dapat mengurangi produktivitas pasien maupun keluarga, kehilangan pendapatan karena tidak bisa bekerja akibat sakit, kehilangan waktu. Biaya hilangnya produktivitas didapatkan berdasarkan Upah Minimum Kabupaten/Kota (UMK) yang hilang selama 
proses perawatan. UMK DIY semakin naik tiap tahunnya. Berikut biaya tidak langsung pada pasien DRESS. Biaya kehilangan pendapatan atau hilangnya produktivitas ini adalah biaya yang paling besar yaitu Rp. 31.832.018 dibandingkan dengan biaya non medis langsung yaitu biaya transportasi dan biaya makanan. Biaya hilangnya produktivitas diukur dengan melihat lama pasien dalam meninggalkan pekerjaan (lama rawat) dan lama anggota keluarga yang menjaga dan menunggu pasien dalam meninggalkan pekerjaan yang kemudian dikalikan dengan pendapat perhari selama tidak bekerja. Dengan kata lain, jika semakin banyak anggota keluarga yang menjaga dan menunggu pasien merupakan anggota keluarga yang dalam usia produktif maka akan semakin besar biaya loss income nya. Akibat semakin meningkatnya rawat inap maka biaya tidak langsung yang dikeluarkan semakin meningkat. Biaya ini menjadi tanggungan tersendiri bagi pasien dan keluarga. Hal ini sesuai dengan (Bingefors et al., 2003) bahwa biaya tidak langsung merupakan pengeluaran sendiri oleh pasien (Out of Pocket) (Aulia et al., 2017).

\section{KESIMPULAN}

Rata-rata biaya medis langsung rawat inap sebesar Rp. 11.643.405. Rata-rata biaya non medis langsung sebesar Rp 491.035 dan biaya tidak langsung adalah sebesar Rp. 1.675.369. Biaya medis langsung merupakan biaya tertinggi dibandingkan biaya non medis langsung dan biaya tidak langsung.

\section{UCAPAN TERIMAKASIH}

Ucapan terima kasih kepada para pegawai di RSUP Dr. Sardjito, baik pegawai dibagian instalasi catatan medik (ICM dan pegawai di instalasi informasi dan tehnologi (INSTI) yang telah membantu kelancaran pengambilan dan pelengkapan data penelitian.

\section{DAFTAR PUSTAKA}

Aulia, D., Ayu, S. F., \& Nefonafratilova, N. (2017). Analisis perbandingan biaya langsung (Direct Cost) dan biaya tidak langsung (Indirect Cost) pada pasien stroke di Rumah Sakit. Jurnal Ekonomi Kesehatan Indonesia, 2(2), 82-88.

Badan pusat statistik. (2016). Indeks harga konsumen, metadata.

Bingefors, K., Pashos, C. L., Smith, M. D., Berger, M. L., Hedblom, E. C., Bingefors, G. W. T. K., ... Torrance, G. W. (2003). Health Care Cost, Quality, and 
Outcomes: ISPOR Book of Terms 1st Edition (1st ed.). ISPOR.

Budiharto, M., \& Kosen, S. (2008). Peranan farmako-ekonomi dalam sistem pelayanan kesehatan di Indonesia. Buletin Penelitian Sistem Kesehatan, 11(4), 337-340.

Chen, Y.-C., Chiu, H.-C., \& Chu, C.-Y. (2010). Drug Reaction With Eosinophilia and Systemic Symptoms. Archives of Dermatology, 146(12), 1373.

Kano, Y., \& Shiohara, T. (2013). Long-term outcome of patients with severe cutaneous adverse reactions. Dermatologica Sinica, 13(4), 211-216.

Sánchez-Borges, M., Caballero-Fonseca, F., Capriles-Hulett, A., \& González-Aveledo, L. (2010). Hypersensitivity reactions to nonsteroidal anti-inflammatory drugs: An update. Pharmaceuticals, 3(1), 10-18.

Tandon, V. R., Khajuria, V., Mahajan, V., Sharma, A., Gillani, Z., \& Mahajan, A. (2015). Drug-induced diseases (DIDs): An experience of a tertiary care teaching hospital from India. Indian Journal of Medical Research, 142(JULY), 33-39.

Wu, X., Yang, F., Chen, S., Xiong, H., Zhu, Q., Gao, X., ... Luo, X. (2018). Clinical, viral and genetic characteristics of drug reaction with eosinophilia and systemic symptoms (DRESS) in Shanghai, China. Acta Dermato-Venereologica, 98(4), 401-405.

Yang, M. S., Kim, J. Y., Kang, M. G., Lee, S. Y., Jung, J. W., Cho, S. H., .. Kang, H. R. (2019). Direct costs of severe cutaneous adverse reactions in a tertiary hospital in Korea. Korean Journal of Internal Medicine, 34(1), 195-201. 